\title{
Indledning til "Tid i sprog" Sproglige tidskategorier - hvad lingvister (måske) kan blive enige om
}

\author{
VOLKMAR ENGERER \\ Statsbiblioteket Århus, Danmark
}

\section{1. "TID I SPROG" - LINGVISTISK KONSENSUS OM TIDSKATEGORIERNE?}

Når lingvister hører udtrykket "tid i sprog", vil de fleste nok umiddelbart tænke på tre ting, tempus, aspekt og aktionsart. Og de otte lingvister, der mødes i dette første temanummer af Sprogforskning, er ingen undtagelse. Sidstnævnte monstrum, aktionsart, er måske det mindst velkendte, iført en tysk lyddragt, der åbenbart klæder det i ethvert sprog. Og det siges, at der findes sprogfolk, der aldrig har hørt om det. Men, selvom det skulle være rigtigt, har de - sandsynligvis - alligevel et begreb om aktionsarterne. Det er fordi aktionsart også har en anden habit i klædeskabet, det engelske "aspect", som aktionsarterne iklæder sig, når de bevæger sig i de finere kredse. Især i den angelsaksiske litteratur bliver "aspect" brugt flittigt om aktionsarterne (Bussmann 1990: 59f., Lyons 1977: 706).

De fleste af de her samlede artikler behandler aspekt i forbindelse med aktionsarter, som, semantisk set, har nogle træk til fælles med aspektbetydninger (men også med tempusbetydninger, se nedenunder). Aspekt kan enten opfattes som mere eller mindre fast forankret grammatisk-morfologisk kategori (se Lund om russisk og, med indskrænkninger, Klein og Bach om de romanske sprog i dette nummer) eller som universelt semantisk fænomen, der realiseres på forskellige måder i alle verdens sprog - og ikke nødvendigvis i morfologien. Disse to teoretiske positioner, den grammatiske og den universalistiske, findes også i forhold til aktionsarterne, hvilket bl.a. er genstand for mit eget bidrag. Aspekt er altså notorisk svært at afgrænse især fra aktionsarterne (hvilket Kleins grundige terminologiske diskussion i dette nummer vidner om), ikke kun pga. ovennævnte uheldige terminologiske sammenfald, men også fordi aspekt grammatisk set trækker på både temporale egenskaber og aktionsartkendetegn, og derfor er den mest "løse" sproglige tidskategori. Tempus kan derimod næsten betragtes som indbegrebet af den "sproglige tid" og fremstår bl.a. derfor som den sproglige tidskategori, der vel er mest enighed om, om end ikke fuldstændigt, som bidragene i dette nummer også vidner om.

Jeg vil derfor i min indledning til dette særnummer om "Tid i sprog" give mit bud på, hvad der måske kan betragtes som "common sense" blandt sprogfolk med hensyn til aspekt, aktionsarter og tempus. Denne gennemgang bliver nødvendigvis meget kursorisk - det gælder især aktionsarterne, som behandles udførligt i mit eget bidrag til dette nummer af Tidsskrift for Sprogforskning. Resten er et kort resumé af de enkelte 
bidrag sammen med en diskussion af deres teoretiske positioner og forbindelser til de andre bidrag i dette nummer. Jeg håber, at jeg på denne måde kan give læseren et mere samlet og kohærent billede af de bidrag, der præsenteres. Selvom udvalget af artikler ved første øjekast måske ser ud til at handle om helt forskellige, sågar usammenlignelige ting, vil jeg prøve at vise, at mange af artiklerne i bund og grund behandler de kerneproblematikker, der altid spiller en fremtrædende rolle i enhver undersøgelse af "Tid i sprog".

\subsection{AsPEKT}

Aspekt er, som jeg allerede har antydet, vist nok den mest "løse" sproglige tidskategori, her er man, i hvert fald i forhold til tempus, meget hurtig til at tale om "aspektløse" sprog vs. aspektsprog. Typiske aspektsprog er de slaviske sprog, fx russisk, der er kendetegnet ved verbale dobbeltformer for henholdsvis det perfektive og det imperfektive aspekt (se også Lunds bidrag i dette nummer). Aspektsfunktionen er ikke at placere en hændelse som helhed på en tidsakse, det er først og fremmest tempus' opgave, aspekt vedrører hændelsens indre tidsstruktur som afsluttet - "perfektiv" - eller som uafsluttet og fortløbende - "imperfektiv". Én og samme hændelse, præsenteret i identiske aktionsartformer og situeret i samme interval i forhold til taletidspunktet, kan derfor ved aspektvariation anskues "udefra", som et helt verbalt forløb med startog slutpunkt, eller "indefra", hvor der fokuseres på en del af hændelsen, uden hele hændelsens start- og endepunkter (se også illustrationerne 1 og 2 i Arndts bidrag i dette nummer). Sådan eller lignende bliver de to aspekter perfektiv og imperfektiv introduceret i en nyere bog om aspekt, Carlota Smiths The Parameter of Aspect (Smith 1997).

Hvordan kan aspekt synliggøres i sprog, der ikke råder over systematiske morfologiske midler til aspektmarkering, som fx dansk eller tysk? Vi ser til dette formål på to, temporalt forskellige situationer, der kan repræsenteres i følgende sætninger:

1a) Klaus kehrte früher aus dem Büro zurück und ertappte seine Frau mit dem Nachbarn 1b) Klaus vendte tidligere tilbage fra kontoret og tog sin kone på fersk gerning med naboen 2a) Klaus kehrte früher aus dem Büro zurück und bemerkte, dass es noch hell war 2b) Klaus vendte tidligere tilbage fra kontoret og bemoerkede, at det stadigvoek var lyst

De tyske sætninger (1a) og (2a), som er komplekse sætninger forbundet med und, repræsenterer to forskellige tidslige forhold. I den første sætning (1a) tog Klaus konen på fersk gerning, efter han var kommet hjem fra arbejde, zurückkehren-handlingen er altså afsluttet, før balladen i hjemmet starter (balladens begyndelse er markeret med ertappen-sætningen). Eksempel (2a) derimod har den foretrukne interpretation, at han bemærkede, at det var lyst, mens han var på vej hjem: zurückkehren-handlingen er altså ikke afsluttet endnu, da bemerken-handling begynder. Vi har dermed to leksikalsk identiske aktionsarter ved siden af verberne (zurückkehren: durativ handling med mål eller en inhærent grænse, ertappen/bemerken: punktuel), men forskellige tidsintervaller med hensyn til afslutning af zurückkehren-handlingen. Dette er i grunden en aspektforskel, dels er prædikatets grænse nået (perfektiv, 1a), dels stræber handlingen bare derhen, men uden at nå prædikatets endepunkt (imperfektiv, 2a). ${ }^{1}$ 
Det er først og fremmest Lunds, Kleins og Arndts bidrag, der trækker på den eller en lignende opfattelse af aspektkategorien. Samtidig tydeliggør disse minimalistiske eksempler i (1) og (2), at aspektkategorien ikke er fuldstændig uafhængig af de andre tidskategorier: Den ovenfor påpegede forskel i aspekt træder kun frem i aktionsartoppositionen accomplishment (telisk-durativ) vs. achievement (punktuel) og har, sammen med den grundlæggende forskel i aspekt, bl.a. som konsekvens, at de to delhændelser i (1) og (2) ændrer deres relative forhold på tidsaksen. I (1) er der tale om to tilstødende intervaller, der ligger efter hinanden, hvorimod delhandlingernes intervaller i (2) overlapper (dog - i begge tilfælde ligger delhandlingernes intervaller før taletidspunktet). Denne kontrast kan beskrives som en tempuskontrast, selvom den bunder i en aspektforskel.

\subsection{AKTIONSART}

Det er heller ikke så nemt at komme frem til et fælles begreb vedrørende de såkaldte aktionsarter. Derfor vil jeg gøre det meget kort og henvise til mit bidrag i dette nummer. Man kan måske blive enige om, at aktionsarter er resultatet af en klassifikation af sproglige udtryk, først og fremmest verber, efter de tidslige egenskaber, som den denoterede hændelse har, eller bedre sagt: efter hvilke tidslige egenskaber, der bliver tilskrevet hændelsen og fremhævet gennem verbets aktionsart (en formulering, som Bach i dette nummer anvender i sin karakterisering af tempusfunktionen). ${ }^{2}$ Aktionsarterne bliver altså traditionelt opfattet som betydningsgrupper inden for verberne (Andersson 1972: 28). Her nogle eksempler. En kategori af hændelser, der bliver betragtet som aktionsart, kan $\mathrm{fx}$ være vedvarende og uden tidslig begrænsning (at sove, fryse, bo, blive) - man taler om den durative aktionsart. Er der derimod anlagt en begrænsning i hændelsesforløbet, er der tale om den terminative aktionsart (hvilket ikke udelukker en durativ karakterisering, sml. at bestige, visne, fuldende). Den punktuelle aktionsart repræsenteres $\mathrm{fx}$ i verber som at møde, finde, gribe, der alle konceptualiserer situationer uden tidslig udstrækning, selvom disse hændelser i virkeligheden selvfølgelig tager tid. Der findes et hav af aktionsarter nævnt i litteraturen, med alle mulige forfinelser, fx inchoativa, der indikerer en overgang fra en til en anden tilstand (at modne), eller udvidelser til ikke primært tidslige kriterier som i intensiva og diminuitiva, der henholdsvis forstærker (ty. schnitzen) eller svækker (ty. hüsteln) intensiteten i en hændelse. ${ }^{3}$

I mit eget bidrag til dette nummer vil jeg vise, at nye teorier om aktionsart er tvunget til at reducere denne mangfoldighed af aktionsartskel til fordel af bibeholdelsen af deres universelle karakter. Mens den deskriptive værdi måske retfærdiggør elaborerede og forfinede aktionsartklassifikationer, bliver klassifikationerne tvivlsomme, hvis de kun i utilstrækkelig grad viser grammatiske reflekser. Denne centrale grundpille i forhold til aktionsarternes eksistensberettigelse bliver - under mottoet "grammatisk relevans" - udførligt behandlet i mit bidrag til dette nummer.

\subsection{TEMPUS}

Der er i dag næsten ingen tvivl om, at temporale relationer, dvs. hændelsers forskellige tidslige situeringer i forhold til enten andre hændelser eller ytringstidspunktet, 
kan udtrykkes i alle sprog. Whorfs påstande om det tempusløse sprog (bedre: sprog uden temporale relationer) ser ud til at have været spøgelser, der er gået i arv i flere lingvistgenerationer næsten som en myte (se hertil fx Pinker 1996: 74f.). Der bør skelnes mellem disse temporale relationer og deres mangfoldige udtryksmidler og tempus, som er det mest specialiserede temporale udtryksmiddel, og som også er et grammatikaliseret fænomen, der obligatorisk markerer sætninger temporalt, typisk ved en tilsvarende fleksion ved verbet. Dette syn på tempus, der fokuserer på den status, som tempus har som verbal-fleksionel grammatisk kategori og samtidig holder leksikalske temporale enheder som tidsadverbialer udenfor tempuskategorien, er, så vidt jeg kan se, det mest udbredte (sml. fx Fabricius-Hansen 1991: 722f. og Vikner i dette nummer).

Begrænsningen af tempus som grammatisk kategori betyder selvfølgelig ikke, at de sprog, der ikke har en sådan systematisk tempusvariation, ikke har noget semantisk begreb om temporale relationer. Det har de, og sætter ord på dem uden problemer - hvis de vil. Lunds kontrastive undersøgelse af en dansk tekst og dens russiske oversættelse i dette nummer påviser klart sprogsystematisk betingede forskelle mellem de to sprog, der får dem til at tage forskellige sprogmidler fra forskellige grammatiske lag (morfologien, leksikon, syntaks) i brug for at udtrykke identiske tidsrelationer. Forskellen mellem sprog med grammatikaliseret og ikke-grammatikaliseret tempus er blot, at talere af den sidste sprogtype har frihed til at lade relationerne være sprogligt uspecificerede, idet man ganske enkelt stoler på konteksten; når konteksten synes for vag, kan der altid trækkes på andre sproglige midler, fx temporale adverbier som for nylig, nu, bagefter (se hertil også Lund i dette bind). Universaliteten af temporale relationer er bl.a. fremhævet af Lyons (1977: 678f.).

Der er åbenbart et universelt kommunikativt behov for at kendetegne fortællingers hændelser både i deres relative tidslige forhold til hinanden ("Hvad kom før og hvad efter?") og i deres tidslige situering i forhold til ytringstidspunktet (før, lig med eller efter taletidspunktet). Tempus kan derfor meget bredt karakteriseres som den sproglige kategori (eller, hvis man føler sig for trængt i det kategoriale korset, som mængden af sprogmidler), der tidsligt situerer en sprogligt repræsenteret hændelse $\mathrm{E}$

(3) i forhold til andre, også sprogligt repræsenterede hændelser H; H’s formmæssige korrelater kan

a) være et syntaktisk led i den samme sætning, hvor også $\mathrm{E}$ er repræsenteret. Det fører typisk til komplekse sætninger, enten parataktiske, med konjunktion ( $\mathrm{fx} \circ \mathrm{g}$ ) eller uden, eller hypotaktiske konstruktioner med indlejrede temporale bisætninger, indledt $\mathrm{fx}$ af temporale konjunktioner. Denne syntaktiske konstellation er domænet for consecutio temporum fænomener. Eller

b) H's syntaktiske korrelater findes i den tekstuelle, sætningsoverskridende omgivelse, som det E-denoterende udtryk er en bestanddel af; Hudtrykkene kan både gå forud for eller komme bagefter E-udtrykket, uden indskrænkning af, hvor lang distancen mellem de to udtryk må være i den tekstuelle kæde. Også i denne tekstuelle konstellation er grammatisk baserede temporale interpretationsteknikker virksomme, herunder E- og H-udtrykkenes aktionsartkarakteristik, som detaljeret er blevet påvist af ter Meulen (1997). Derudover kommer der rent tekstuelle 
interpretationsteknikker til anvendelse, som i langt højere grad end (3a) bygger på individuel tekstforståelse og, også i forskellig grad, viden om verden. Desuden sørger tempus for

(4) E's tidslige situering i forhold til sætningens ytringstidspunkt. Denne anden funktion kan også betegnes som den deiktiske funktion af tempus.

Disse to punkter er måske dér, hvor de fleste lingvister kan mødes.

Derimod er meningerne mere delte, når det gælder spørgsmålet om, hvordan tidsstrukturen i sprogs semantiske lag bedst beskrives. Er det, som man kunne tænke sig, en enkelt to-steds-relation mellem ytringstidspunktet på den ene side og hændelsens tidspunkt på den anden side, hvormed der ordnes hændelser før (datid), samtidig med (nutid) og efter taletidspunktet (fremtid)? Denne traditionelle og intuitivt indlysende tilgang er "direkte" i den forstand, at den direkte knytter hændelsens tid, altså det, der peger på den centrale samtalegenstand, til det givne ytringstidspunkt, der som regel altid refererer til den for taleren og lytteren fælles kommunikationssituation. At forbinde et "bevægeligt" punkt, hændelsestidspunktet, med et givent, fast og for alle i situationen genkendeligt ytringstidspunkt ved hjælp af et enkelt før-efterforhold (hvor nutid hverken er før eller efter) har i lang tid været den oplagte måde at beskrive tidsrelationer på. Denne tilgang ligger til grund for mange grammatikkers beskrivelser af tempussystemer, fx den tyske Dudengrammatik (Duden 1998: 146ff.). Det er betegnende, at ikke en eneste af de her samlede bidragsydere benytter sig af denne direkte, to-punkts-tilgang (en undtagelse er måske Bach, som i ikke altid anser indførelsen af flere tidspunkter som nødvendig).

En anden, imidlertid meget indflydelsesrig teori om den temporale struktur i sprog stammer fra filosoffen Reichenbach (Reichenbach 1947), der som den første postulerede tre i stedet for to punkter i repræsentationen af tid, som efter hans opfattelse er uundværlige for en empirisk adækvat beskrivelse af tidsstrukturen i sprog. De fleste af de her forsamlede bidrag rekurrerer også til denne mere elaborerede teori. Reichenbachs tredje punkt, referencetidspunktet, kommer umiddelbart til syne i fx pluskvamperfektum og andre af de typisk mere komplekse tempora, hvor der kræves yderligere et tidspunkt, som hændelsens tid kan placeres i forhold til. Analogt hermed, og der findes selvfølgelig også uafhængige argumenter, må dette tidspunkt altså også være tilstede i de andre, simple tempora som præteritum eller præsens. Denne tilgang, som er "indirekte" forstået sådan, at den kun middelbart, nemlig via en omvej over referencetidspunktet, forbinder ytringstidspunktet med hændelsestidspunktet, er blevet modificeret og tilpasset flere gange, fx i Vikner (1985) og Vikner i dette nummer, og er også blevet anvendt i andre sprog, fx tysk (sml. Wöllstein-Leisten et al. 1997: 77-92). Også formale tempusteorier trækker på Reichenbachs tre-punkts-analyse (se fx Cann 1993 eller Lohnstein 1996).

Reichenbachteoriens foreløbige højdepunkt findes i Hornsteins bog As Time Goes By fra 1990 (Hornstein 1990), som fremlægger en up-to-date generativistisk, empirisk underbygget og udvidet neo-Reichenbach tempusteori. I øvrigt har det forbavset mig at se, hvordan disse mere eller mindre tilfældige ti sider om tempus i Reichenbachs 
bog, der under titlen Elements of Symbolic Logic i virkeligheden handler om noget meget større og alment, nemlig symbollogik (Reichenbach 1947: 287-298), har kunnet påvirke en forskningsretning i den grad.

\section{2. "TID I SPROG" - GRUNDPROBLEMER}

\subsection{Aktionsarternes leksikalske basis (KLein)}

Fran z-Josef Klein, Romansk Institut, Universitetet i Siegen (Tyskland), belyser ud fra den romanistiske forskningstradition både klassiske og nyere studier vedrørende aspekt og aktionsart, især i analyser af fransk. Han påpeger, at også romanistikken i sin lange historie nogle gange har haft svært med at sætte et skarpt skel mellem aspektog aktionsartfænomener, hvilket ikke altid har været gavnligt for sproganalysernes fremgang. Ved siden af den grundige terminologiske diskussion af begrebsparret aktionsart/aspekt fremlægger Klein en dybtgående semantisk analyse af de franske sanseverber voir og regarder. Han viser, at disse verbers betydning indlysende kan beskrives i aktionsartbegreber, og at de aktionsartoppositioner, der kommer til syne her, ikke er et isoleret fænomen i det franske sprog, men kan udvides til en række andre verber.

Det fremgår tydeligt af Kleins bidrag, at sprogenes verbale leksikon, i det mindste delvist, er struktureret langs aktionsart-dimensioner, og at disse semantiske kategorier ikke altid behøver at slå sig ned i grammatiske oppositioner i fx morfologien. Det betyder naturligvis ikke, at aktionsarter ikke har formale korrelater! Kleins sammenkobling af verbernes syntaktiske adfærd med deres aktionsartsemantiske træk er et klart udtryk for, at $\mathrm{fx}$ punktuelle eller durative kendetegn i verbernes leksik har syntaktiske, og dermed formale reflekser, som $\mathrm{fx}$ viser sig i deres valens eller deres adfærd i kombination med andre sprogelementer, her først og fremmest adverbialer. I mit eget bidrag til dette nummer, som betragter aktionsarter fra et mere metodologisk standpunkt, bliver denne fremgangsmåde karakteriseret som "sprogkombinatorisk grammatisk relevans" og "syntaktisk aktionsart".

Selvom denne forbindelse mellem tidsmæssige leksikalske strukturer og sætningers grammatiske byggeprincipper bliver mere og mere åbenlys i den nyere forskning omkring sproglige tidsfænomener, mangler der, og også her har Klein ret, mere omfattende og helhedsorienterede undersøgelser af den tidsmæssige strukturering i et sprogs leksikon. Først når man bevæger sig væk fra den fragmenterede analyse af enkelte verber hen mod en systematisk gennemgang af et sprogs verbbestand, kommer tidskategoriernes virkelige kognitive relevans i sprogenes leksikalske grundlag til syne. Forslag i den rigtige retning er, udover det ældre, men ikke desto mindre inspirerende studie Transformative, intransformative und kursive Verben (Fabricius-Hansen 1975) uden tvivl J. Pustejovskys bog The generative lexicon (Pustejovsky 1995), hvor der udvikles et fælles format til beskrivelse af leksikonenhedernes semantiske og formale egenskaber; det er ikke nødvendigt at sige, at tidsrelaterede egenskaber først og fremmest af verber spiller en fremtrædende rolle i hans analyser. Men - bogens hensigt er langt fra at give en fornemmelse af et sprogs mangfoldige tidsmæssige leksikalske oppositioner og struktureringsprincipper, hvilket ville kræve et leksikon i egentlig forstand (og det var ikke Pustejovskys sigte). 
Sådan et "leksikon" foreligger faktisk for det tyske sprog, nemlig Th. Ballmers og W. Brennenstuhls Deutsche Verben. Eine sprachanalytische Untersuchung des deutschen Verbwortschatzes fra 1986 (Ballmer/Brennenstuhl 1986). Selvom denne teoretisk velfunderede undersøgelse af det tyske verbale leksikon ikke betjener sig udtrykkeligt af aktionsartterminologien, kan både undersøgelsens teoretiske grundlag og bogens deskriptive resultater gøres nyttige ved en decideret påvisning af sproglige tidskategoriers betydning i et sprogs leksikalske system. I Engerer (2000b: 103-106) har jeg forsøgt at eksplicere Ballmer/Brennenstuhls begreb "faseverber" som fx 'ikke være tilfældet' eller 'begynde', der på en dekompositionel måde strukturerer betydelige dele af leksikonet. Dette struktureringsprincip kan med gevinst overføres til en mere moderne og udvidet opfattelse af aktionsart og integreres i en gængs grammatikformalisme som Montagues (Engerer 2000b: 106-109; se også Dowty 1990, Cann 1993 og Chierchia/ McConnell-Ginet 1990).

\subsection{TIDSKateGorieRneS INTERAKTION PÅ DET TEKSTUELLE PLAN (LUND)}

Også Karl-Hen rik Lund, Slavisk Institut, Aarhus Universitet, kommer i sit bidrag ind på forholdet mellem aspekt, aktionsart og tempus, med udgangspunkt i den slavistiske tradition og især i analyser af russisk sprog. Det skal fremhæves, at Lund ikke forbliver i den traditionsrige aspekt- og tempusforskning inden for slavistikken, men også inddrager den angelsaksiske forskningsretning inden for verbale tidskategorier, som er repræsenteret fx med Reichenbach (1947) i forbindelse med tempus og, især hvad aktionsart/aspekt angår, med Vendler (1967) og i nyeste tid Smith (1997).

Lund er sig bevidst om faren, når man bevæger sig væk fra af de "sikre" egne i den russiske aspektforskning hen mod de "vestlige" tilgange til aktionsart og aspekt, hvor skellet mellem disse to kategorier ofte truer med at forplumre (se hertil Steinitz 1981 og mit eget bidrag). Han bemærker fx, at "[...] man kan sætte spørgsmålstegn ved formålstjenligheden af at operere med en særlig aspekt i forbindelse med situationstyperne" (Lund i dette nummer; "situationstyper" svarer til aktionsarter). Ikke desto mindre lykkes det for ham at udnytte den integrerende måde at analysere aspekt og aktionsart på, som forfægtes af engelskorienterede studier (under inddragelse af den danske linje i aspektforskning, fx Durst-Andersen 1992), i en tekstorienteret og kontrastiv dansk-russisk analyse af den sproglige repræsentation af tidskategorier i de to sprog. Her, og det er vist om kernepunktet i Lunds analyse, indtager han et decideret sprogfunktionelt standpunkt, idet han konstruerer et enkeltsprogsoverskridende begreb om "narrativt forløb", som indeholder både aspektuelle, aktionsartmæssige og temporale relationer i en fortælling. Disse relationer skal, hvis der er tale om det samme hændelsesforløb i de to sprog, realiseres i begge tekster - og det bliver de også, men på hver sin måde, afhængigt af det tilsvarende sprogsystems muligheder og grammatiske træk. Dansk og russisk gør brug af forskellige og enkeltsprogsspecifikke sprogmidler for at signalere de samme tidsrelationer.

Lunds undersøgelse viser for det første, hvor vigtigt det er at finde frem til en integreret analyse af aktionsart, aspekt og tempus. Selvom det her drejer sig om adskilte tidslige kategorier, bliver de brugt gensidigt til at signalere den anden kategoris 
værdi. Denne interaktion mellem tidsrelationer indbyrdes er måske mest kendt og udforsket i forbindelse med aspekt-aktionsart-interrelationer. Men også aktionsart og tempus kan stå i et sådant forhold, se fx ter Meulen (1997), at interpretationen af tempusrelationer baseres på nogle få, universelle aktionsarter (se hertil også Engerer i dette nummer under "Betinget universalisme"). For det andet henviser Lunds bidrag til nødvendigheden af at udvide analysen af tidsrelationer til tekstniveauet, hvor forankringen af forskellige tidspunkter (referencetidspunkt, begivenhedsøjeblik m.m.) og hændelsernes tidslige orden samt tekstforfatterens og de talende personers forskellige perspektiver på hændelserne sprogligt realiseres. Analyser af tidsrelationer trænger til hold i virkeligheden, og denne virkelighed kan kun opnås, hvis analysen betragter sproglige udtryk som bestanddele af ytringer og tekster, der refererer til dele af vores virkelighed. Modelbegrebet i den formale semantik er vel nok det klareste udtryk for denne "selvfølgelighed".

Mit bidrag til dette nummer handler udelukkende om aktionsarter. Mine overvejelser skal i mindre grad anses som en analyse af aktionsart i sproget (eller et sprog), men snarere som en analyse af teorier om aktionsart. Det er mit sigte at finde frem til de ingredienser, som en empirisk orienteret og moderne teori om aktionsarter kan sammensættes af. Jeg tror, at mange af de hovedtendenser, som efter min mening udgør en adækvat og integreret aktionsartteori, dvs. en teori, der også tager højde for aktionsarternes indlejring i selve grammatikteorien (og her især i det syntaktiske modul), kan iagttages i de to ovennævnte bidrag af Klein og Lund. De arbejder begge med et meget begrænset antal aktionsarter ("aktionsart-reduktionisme"). Desuden har både Klein og Lund det formmæssige realiseringsaspekt for øje, Klein i form af en mere traditionel analyse af forbindelsesrestriktionerne ved aktionsartudtryk på sætningsplan ("grammatisk relevans", se Engerer i dette nummer), hvorimod Lund på en induktiv måde analyserer sig frem til de grammatiske og leksikalske udtryksformer, der kan signalere tidslige relationer i et sprog. Både Klein og Lund sigter åbenbart til det, jeg beskriver som "syntaktisk aktionsart", altså den måde, hvorpå det oprindeligt leksikalske fænomen aktionsart systematisk udfolder sig fra syntaktiske konstituenter til sætningsniveau. Især Lunds bidrag peger på, at sætningen som øverste grænse for analysen skal overskrides, hvilket jeg i min analyse ikke har taget i betragtning. Jeg tænker fx på to-sætnings-tekster som den nedenstående.

\section{5) Ole holdt op med at ryge for 20 år siden. Nu er han begyndt igen}

Der er ikke kun implikationen, at Ole røg før tidspunktet, hvor han holdt op (se Fabricius-Hansen 1975: 91f.), som er forårsaget af den første sætning, men også den ingressive aktionsart ved siden af verbet begyndt i den anden sætning, som henter sit argument (via ellipse) fra forgængersætningen (at ryge) og udvider på denne måde aktionsartkendetegnet til hele to-sætnings-sekvensen. Syntaktisk aktionsart i snæver forstand, som den afspejler sig i mit bidrag til dette nummer, kan altså godt vise sig at være utilstrækkelig. 


\subsection{EN RIGOROS TIDSSEMANTIK (VIKNER)}

Sten Vikner, Engelsk Institut, Universitet Aarhus, tager i sin artikel vel mest udpræget af alle udgangspunkt i Reichenbachs tempusteori. Han betragter tempus som et sprogligt delsystem, der morfologisk manifesterer sig i et enkeltsprogligt sæt af tempusformer, som også semantisk skal kunne beskrives på en konsistent og sammenhængende måde. Han fremfører dels modsigende analyser af tempussystemer i en række vidt forskellige sprog, udover dansk, tysk og engelsk også albansk, yoruba, tyrkisk, hawaiiansk og finsk. Vikners afgørende kriterium for holdbarheden af en given tempusanalyse er, om der kan etableres fuldstændig parallelitet mellem tempusformernes betydning og deres morfologiske opbygning og struktur. For at opnå dette formål, er det ifølge Vikner nødvendigt at indføre et andet referencetidspunkt, således at det nu modificerede Reichenbach-system består af fire punkter, ytringsog begivenhedstidspunktet samt to referencetidspunkter. Denne udvidelse åbner nu muligheden for at kæde disse fire tidspunkter sammen ved hjælp af tre binære relationer, der bestemmer det relative tidslige forhold mellem to punkter på grundlag af en enkelt før-efter-relation. [PRÆT] som det første led definerer forholdet mellem taletidspunktet og det første referencetidspunkt, fulgt af [POST], der ordner forholdet mellem de to referencetidspunkter indbyrdes. Den tredje relation betegnes som [PERF], hvor det er det andet referencetidspunkt, der endelig sættes i forhold til begivenhedstidspunktet. Med denne semantiske karakterisering lykkes det Vikner at tilordne præcis ét morfologisk korrelat til hver relation (fx [PRÆT], ...) og tilordne hver relation en værdi (fx [+PRÆT], [-PRÆT], ...).

Det er uden tvivl en elegant løsning, som også kommer de moderne teorier i møde, der er baseret på en systematisk forbindelse mellem semantik og form. Desuden viser Vikners stringente holden fast i en fuld overensstemmelse mellem semantiske træk og deres systematiske grammatisk-morfologiske reflekser vejen frem mod en tilsvarende behandling af aktionsart-delsystemer, hvor der kan opstå lignende paralleliteter. Fx i tysk kan mange handlingsverber, især fremdriftsverber, men også taleverber som reden, præfigeres med los-, hvilket resulterer i den ingressive aktionsart ved det nye leksem (loslaufen, losfliegen, losreden, losschreiben, losraten ...). En lignende ingressiv aktionsart opnås også syntaktisk ved tilføjelsen af det pågældende faseverbum (se også Engerer 1999, 2000a, 2000b, 2001 og 2002).

6) beginnen zu laufen (zu fliegen, zu reden, zu schreiben, zu raten ...)

Det samme gælder for weiter- i fx weiterlaufen, weiterschlafen, weiterarbeiten osv., hvor leksemerne får tilknyttet den kontinuative aktionsart. Også her findes en syntaktisk konstruktion, der er specialiseret i den samme aktionsart:

fortfahren zu laufen (zu schlafen, zu arbeiten ...)

Og rækken kunne fortsættes. Der er efter min mening en interessant parallelitet mellem disse systematiske morfologisk-syntaktiske reflekser ved aktionsartsemantikken og Vikners postulerede forhold mellem semantik og form på tempusområdet. I hans system findes der semantiske tempusrelationer, der dels korrelerer med fleksionsformer af 
det samme leksem (fx [+PRÆT] med verbets præteritumsform) og dels med variation af et selvstændigt hjælpeverbum (fx [+POST] med hjælpeverberne ville/will/werden). På en lignende måde korrelerer de omtalte semantiske aktionsarter ingressivt og kontinuativt både med et deriveret leksem (los-laufen, weiter-laufen) og med syntaktiske konstruktioner som i (6) og (7), hvor faseverberne kan minde om hjælpeverbernes funktion ved dannelsen af sammensatte tempusformer. En skønhedsplet, dvs. en af det tyske morfologiske systems ikke projekterede muligheder, er den egressive aktionsart (fx aufhören zu laufen), som på tysk ikke råder over et morfologisk korrelat. Selvom disse muligheder er begrænsede i visse sprog, herunder tysk - sammenlignet med Vikners konception af tempussystemet -, danner faser (begyndelse, fortsættelse og slutning) dog et alment tilstrækkeligt indhold, der parallelt med tempussemantikken kan strukturere både det morfologiske og det syntaktiske udtryk ved aktionsartdistinktioner.

\subsection{EN MODPOSITION TIL EN RIGOROS TIDSSEMANTIK: MODALITET (ARNDT)}

Hans Arndt, Institut for Lingvistik, Aarhus Universitet, bidrager til dette nummer, så at sige, med en modvægt til Vikners skrappe parallelisering af semantikkens temporale relationer og deres morfologiske udtryksformer. Mens Vikners tese, i hvert fald efter min opfattelse, implicerer en en-til-en-relation mellem hans tre semantiske "træk" og de temporale udtryks (verbaltemporale fleksionsformers og hjælpeverbers) aktuelle betydninger, er Arndts holdning i denne henseende mere skeptisk. Han leverer en række - først og fremmest engelske og danske - eksempler, der demonstrerer, at tidsformer, i hvert fald i de to analyserede sprog, ofte ikke kun udtrykker basale tidsrelationer, men også modale betydninger. Selvom Arndt accepterer et "umarkeret indhold" af fx tempus (som ligner Vikners konception af tidssemantikken), nægter han på baggrund af sit materiale en simpel en-til-en-korrespondance mellem temporale udtryk og indhold.

Jeg tror ikke, at de to positioner ligger så langt fra hinanden, som det måske kunne se ud til ved første øjekast. For det første viser Arndts eksempler jo ikke, at de basale temporale betydninger fuldstændig er sat ud af kraft; de træder bare i baggrunden til fordel for en anden betydning, som Arndt bemærker til følgende eksempel (eksempel (10a) i Arndt, i dette nummer):

8) Jeg skal nok komme og besøge Dig (reassurance, with both a modal verb and the modal particle nok, 'Don't worry, I'll come and see you')

I eksempel (8) er futurumbetydningen til stede, på trods af det dominerende modale element, forstærket med partiklen nok. Der er uden tvivl en forbindelse mellem tidsbetydning og modale interpretationer på udtryksplanet, hvilket også er et meget omdiskuteret emne inden for fx den germanistiske lingvistik (se fx Engel 1988: 495). Men det betyder ikke nødvendigvis, at rene tempusbetydninger vil blive obsolete. For det andet antyder Arndt muligheden for, at tempuskategoriernes semantik simpelthen er formuleret for snævert. Det temporale forhold før-efter er en underklasse (instantiering) af en større kategori "aktualitet", hvilket han illustrerer i forbindelse med præsenspræteritum-skellet med det deiktiske par "this"/"that" i stedet for den rene temporale semantisering med parret "now"|"then". Denne hypotese, som også forfægtes af Østergaard i dette nummer, er ikke så nem at forene med Vikners analyse, men lad mig 
henvise til, at en kognitiv konceptualisering af hele tempora, som Arndts ovennævnte generalisering efter min mening sigter til, er et noget andet fortagende end Vikners rent grammatiske sigte. Vikner prøver at formulere temporalmorfemernes semantik dels så tilstrækkeligt bred, at den kan omfatte alle empiriske, temporale differentieringer, dels så snæver, at der kan formuleres en semantik til enkelte morfemer på det morfologiske niveau. Og hvis der kunne formuleres en systematisk relation mellem det kognitive plan (Arndt og Østergaard) og det sproglig-semantiske plan (Vikner), ville der overhovedet ikke være nogen ufordrageligheder mellem de to positioner.

\subsection{Genfforeningen af den rigorose tidssemantik med Tekstuelle tidsbetydninger (Bach)}

Svend Bach, Romansk Institut, Aarhus Universitet, behandler tempus og aspekt i italiensk og kommer også ind på spørgsmålet, om der kan formuleres "faste" temporale betydninger, som det postuleres af Vikner i dette nummer, eller om temporalformernes semantik skal udformes så bredt, at den også dækker alle de andre "betydninger", der kommer til syne i sætningers forskellige syntaktiske kontekster og ytringers skiftende kontekstforhold. Bachs holdning er entydig: Det er ikke hensigtsmæssigt at tilskrive, som han udtrykker det, "tekstfunktioner" til de enkelte tidsmorfemers semantiske struktur. På dette baggrund tilbageviser han både det kendte skel mellem fortællende/ kommenterende tempora og forgrund/baggrund, fremsat af Weinrich (1971). I hans eksempler viser det sig, at disse "betydninger" aldrig er nødvendige interpretationer, kernetemporale betydninger er altså altid til stede. På baggrund af dette går han derfor ind for et enkelt italiensk system med primitive semantiske features både for tempus ([+/-fremtid] og [+/-fortid]) og aspekt ([+/-afgrænset]), som i fællesskab kendetegner de italienske tempusformer.

Også Bach gør, ligesom Vikner, brug af Reichenbachs konception af de tre tidspunkter, med den forskel, at dér, hvor Vikner tilføjer et yderligt referencetidspunkt, fjerner Bach referencetidspunktet fra analysen af enkelte tidsmorfemer, som han dog anser som "[...] et nødvendigt instrument for analysen af de virkninger, der opstår, når flere tidsudtryk (verbalformer og adverbialer) arbejder sammen i en tekst", men som er "[...] irrelevant for formernes definitioner" (Bach, i dette nummer). Der er altså også de såkaldte "sammensatte tempora", som ifølge Bach skal betragtes som syntaktisk sammensatte og tekstuelt interpreterede enheder og som derfor ikke får deres samlede semantiske værdi fra leksikonet "i et hug".

Under overskriften "Manglende overensstemmelse mellem tempusmarkeringer og den ekstrasproglige tid" kommer Bach nu ind på det centrale spørgsmål, hvordan en fast tempusbetydning på morfemniveau kan være forenelig med syntaktiske udtryk, hvis samlede tidsreference er forskellig fra tidsmorfemernes leksikale betydning. I denne forbindelse bemærker Bach helt grundlæggende: Tempusformer præ s e n t e r e r den denoterede handling som lokaliseret på eller omkring et bestemt punkt på tidsaksen, hvilket ikke er ensbetydende med, at denne lokalisering også bør afspejle forholdene i den ekstrasproglige virkelighed. På denne måde lykkes det Bach på den ene side at opretholde temporalsemantikkens gyldighed også i aktuelle ytringer og på den anden side systematisk at tage højde for de talrige syntaktiske og talerrelaterede afvigelser, 
som kan iagttages i kontekstuelt indlejrede ytringer. Herunder regner Bach consecutio temporum-fænomener samt "overført betydning af tempus", altså tilfælde som den kendte historiske præsens. Under forudsætningen af præsentationshypotesens gyldighed (se ovenfor) kan Bach overbevisende argumentere for, at tempusmorfemerne også i disse afvigelsestilfælde beholder "en del af deres egen grundbetydning".

Man kan vel foreløbig konstatere, at Vikners præcise formulering af en relativ primitiv tidssemantik i forbindelse med Bachs analyse af fremkomsten af temporale "bibetydninger" på tekstniveau er stærke argumenter for at trække et skarpt skel mellem semantisk og tekstuel tempus. I denne sammenhæng skal også ses Lunds kontrastive tekstanalyse, som på tempusområdet også trækker på Reichenbachs teori og kan nøjes med et sæt af relativt enkle temporale relationer. Den narrative, herunder også den temporale progression, udfolder sig her først på tekstplan (se appendiks til Lunds bidrag i dette nummer), hvor de enkelte verbalhandlinger er entydigt ordnet i forhold til hinanden på en fiktiv tidsakse.

\subsection{Fra teKST TIL KOMMUNIKATION: TIDSBETYDNINGERS PRAGMATISKE OG KOGNITIVE FUNDERING (ØSterGaARD)}

Svend $\varnothing$ stergaard, Center for Semiotik, Aarhus Universitet, fremlægger en grundig analyse af nogle adverbialers tidsrelaterede semantik (allerede, stadig, endnu, endelig, snart og deres engelske ækvivalenter). Han går et skridt længere end i de andre hidtil omtalte bidrag, idet han til tidsbetydningers sprogsystematisk-semantiske koncept samt de tekstrelaterede aspekter af tidsudtryk føjer en talerrelateret dimension af udsigerens forventninger, som knytter sig til brugen af de ovennævnte adverbiale udtryk. Det kan fortolkes som den konsekvente udvidelse af Bachs konception vedrørende tekstuelle tidsbetydninger. En sætning som Han er allerede foerdig har bl.a. den tidslige betydning, at han er færdig på et tidspunkt før taletidspunktet. Men desuden signalerer den, at denne kendsgerning står i modsætning til udsigerens forventning, som består $i$, at han først bliver færdig på et tidspunkt efter taletidspunktet. Østergaard interpreterer dette forhold mellem tidsudtrykkenes faktiske referencemåde og udsigerens modstridende forventninger omkring den tidslige reference som to samtidige repræsentationer i taleren, én faktuel situering før taletidspunktet og én konterfaktuel efter taletidspunktet. Østergaards analyser fører til en interessant hypotese om disse adverbialers semantik, nemlig at det tidsrelaterede betydningslag, der fremkommer, er en instantiering af et ikke-tidsligt mønster, "[...] hvor en tilstand afhænger af en skala [...] og hvor adverbiet implicerer en konflikt mellem udsigerens mentale repræsentation af, hvor på skalaen tilstanden er placeret, og hvor den faktisk befinder sig" (Østergaard i dette nummer).

Østergaards analyse af tidslige relationer kan for det første interpreteres som en udvidelse af det tekstuelle kontekstbegreb, som fx anvendes af Bach og Lund i dette nummer, til et pragmatisk funderet kontekstbegreb, hvor den talendes mentale tilstande indgår som afgørende komponent, ikke ulig J. Searles og D. Vandervekens formale rekonstruktion af kontekst i deres analyse af sproghandlinger (Searle/Vanderveken 1985). Denne talerrelaterede udvidelse af kontekstbegrebet i forbindelse med den semantiske analyse af tidsadverbier er konsekvent og nødvendig, fordi Østergaards undersøgelsesobjekt er "naturlige" kommunikationssituationer med direkte involverede 
kommunikanter, hvorimod Bachs og Lunds analyser af tidsrelationer fokuserer på narrative tekster, hvor en "talende" optræder enten som (en abstrakt) fortæller (tekstens forfatter eller en fiktiv person i teksten, der fortæller) eller som figur, hvis talerrolle igen bliver fortalt. En sådan rent tekstuelt sammensat undersøgelsesgenstand tillader, at der abstraheres fra den talendes aktuelle mentale tilstande. Naturlig kommunikation er derimod ikke til at komme til livs ved at se bort fra udsigeren.

For det andet påviser Østergaard muligheden for at spore tidsbetydninger tilbage til en ikke-tidslig, overordnet betydning, som består, noget forenklet udtrykt, i en pragmatisk betingelse, nemlig en manglende indfrielse af den talendes forventninger. Den tidslige interpretation af hændelsernes mentale repræsentationer på en (mental) tidsakse sker så at sige uden for udtrykkenes kernesemantik, den baserer sig på kontekst- og vidensafhængige interpretationsteknikker. På dette punkt kan Østergaards analyse knyttes sammen med Arndts skepticisme over for rent semantisk forankrede temporale betydninger (se Arndts generalisering ovenfor).

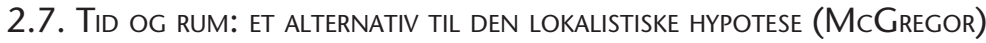

Willia m Mc Gregor, Institut for Lingvistik, Aarhus Universitet, tyvstarter et angreb mod den stærke version af den lokalistiske hypotese, ifølge hvilken de sproglige tidskategorier har deres oprindelse i rumkategorier, og forbindelsen mellem rum og tid er stiftet via en metaforisk overføring. Han viser ved hjælp af et omfangsrigt materiale fra australske aboriginal-sprog, at det her ikke var rummet, der dannede forbillede for tidskategorierne, men derimod den semantiske relation af ledsagelse (komitativ relation). Dens morfemer er trængt fra deres "rette" plads ved nominalet (med Ole) ind i det verbale domæne, hvor de nu markerer tempus- og aspektkategorier. Det er efter min mening en bemærkelsesværdig proces. Selvom sammensmeltninger af forhenværende frie morfemer med andre sætningselementer ikke er ukendte (se fx de tyske personalendelser ved verbet, som er det diakroniske resultat af en sammensmeltning af verbets stamme og personalpronomen, Eisenberg 1994: 112), er der i de omtalte australske sprog her tale om et bundet morfem, der både skifter basiskategorien i forhold til den ordklasse, det forbinder sig med (fra nomen til verbet), og betydning (fra komitativ til tidslig).

\section{TIL SIDST}

Det er mit håb med disse overvejelser at kunne vise, at de her samlede lingvister enes i det mål at i) finde frem til en holdbar konception af tidsbetydninger, ii) at fastslå tidskategoriernes status i den grammatiske opbygning af sproget og iii) at forbinde i) og ii) på en konsistent måde med tidskategoriernes skiftende funktioner i aktuelle ytringer og tekster - det kan nogle gange være særdeles vanskeligt at få fat i. Vejene derhen er selvfølgelig forskellige, alt afhængigt af det undersøgte sprog, den tidskategori, som den enkelte forfatter har fokuseret på, og - last but not least - de lingvistiske traditioner og skoler, forfatteren er bundet af. På denne baggrund er det efter min mening forbavsende, hvor mange fællestræk der alligevel er kommet til syne.

God fornøjelse og god læselyst med dette første nummer af Tidsskrift for Sprogforskning! 
Engerer, Indledning

\section{LITTERATUR}

Andersson, Sven-Gunnar (1972), Aktionalität im Deutschen. Eine Untersuchung unter Vergleich mit dem russischen Aspektsystem, Bd. 1, Die Kategorie Aspekt und Aktionsart im Russischen und Deutschen, Uppsala: Skriv Service AB.

Ballmer, Thomas Waltraud Brennenstuhl (1986), Deutsche Verben. Eine sprachanalytische Untersuchung des deutschen Verbwortschatzes, Tübingen: Gunter Narr Verlag.

Bussmann, Hadumod (1990), Lexikon der Sprachwissenschaft, Stuttgart: Kröner.

Cann, Ronnie (1993), Formal Semantics. An introduction, Cambridge: Cambridge University Press.

Chierchia, Gennaro, Sally McConnell-Ginet (1990), An Introduction to Semantics, Cambridge/Mass., London: MIT Press.

Dowty, David R. (1990), Word meaning and Montague Grammar, Dordrecht: Kluwer Academic Publishers.

Duden (1998), Die Grammatik, Mannheim etc.: Dudenverlag.

Durst-Andersen, Per (1992), Mental Grammar. Russian Aspect and Related Issues, Columbus, Ohio: Slavica Publishers.

Eisenberg, Peter (1994), Grundriss der deutschen Grammatik, Stuttgart, Weimar: Metzler.

Engel, Ulrich (1988), Deutsche Grammatik, Heidelberg: Groos.

Engerer, Volkmar (1999), "Phasenverbkomplemente", Studia Germanica Universitatis Vesprimiensis, 3/2 (1999), pp. 145-159.

Engerer, Volkmar (2000a), "Was lässt sich im Deutschen aufhören und beenden? Aspekt, Aktionsart und nominale Komplementation intervallabschlussdenotiere nder Phasenverben", in: Lindberg, Carl-Erik, Steffen Nordahl Lund (red.) (2000), $17^{\text {th }}$ Scandinavian Conference of Linguistics, Vol. I (= Odense Working Papers in Language and Communication, No. 19, April), Odense: Institute of Language and Communication, pp. 171-186.

Engerer, Volkmar (2000b), "Phasenverbsemantik", in: Dorfmüller-Karpusa, Käthi, Ekaterini Vretta-Panidou (Hgg.) (2000), Thessaloniker Interkulturelle Analysen. Akten des 33. Linguistischen Kolloquiums in Thessaloniki 1998, Frankfurt/Main etc.: Peter Lang, pp. 101-110.

Engerer, Volkmar (2001), „Phasenverben brauchen Zeit: Die zeitsemantische Verankerung von Satzgliedern“, Studia Germanica Universitatis Vesprimiensis, 5/1 (2001), pp. 5-20.

Engerer, Volkmar (2002), "Faseverbernes tidsbetingelse. Grundtræk af den semantiske beskrivelse af faseverbkonstruktioner", Hermes - Journal of Linguistics, 29 (2002), pp. 53-71.

Fabricius-Hansen, Cathrine (1975), Transformative, intransformative und kursive Verben, Tübingen: Max Niemeyer Verlag.

Fabricius-Hansen, Cathrine (1991), "Tempus", in: Stechow, Armin von, Dieter Wunderlich (Hgg./eds.) (1991), Semantik. Semantics: Ein internationales Handbuch der zeitgenössischen Forschung (= Handbücher zur Sprachwissenschaft und Kommunikatio nswissenschaft Bd.6.), Berlin, New York: de Gruyter, pp. 722-748.

Hornstein, Norbert (1990), As Time Goes By. Tense and Universal Grammar, Cambridge/ Mass., London: MIT Press. 
Engerer, Indledning

Lohnstein, Horst (1996), Formale Semantik und natürliche Sprache, Opladen: Westdeutscher Verlag.

Lyons, John (1977), Semantics, Vol. 2, Cambridge: Cambridge University Press.

Pinker, Steven (1996), Der Sprachinstinkt, München: Kindler.

Pustejovsky, James (1995), The generative lexicon, Cambridge/Mass.: MIT Press.

Reichenbach, Hans (1947), Elements of Symbolic Logic, New York: Macmillan.

Searle, John, Daniel Vanderveken (1985), Foundations of illocutionary logic, Cambridge, New York: Cambridge University Press.

Smith, Carlota (1997), The Parameter of Aspect, Dordrecht, Boston, London: Kluwer Academic Press.

Steinitz, Renate (1981), Der Status der Kategorie "Aktionsart" in der Grammatik (oder: Gibt es Aktionsarten im Deutschen?), Berlin: Zentralinstitut für Sprachwissenschaft der Akademie der Wissenschaften der DDR (= Linguistische Studien, Reihe A: Arbeitsberichte 76).

ter Meulen, Alice G. B. (1997), Representing Time in Natural Language. The Dynamic Interpretation of Tense and Aspect, Cambridge/Mass., London: MIT Press.

Weinrich, Harald (1971), Tempus. Besprochene und erzählte Welt, Stuttgart: Kohlhammer.

Vendler, Zeno (1967), "Verbs and Times", in: Vendler, Zeno (1967), Linguistics in Philosophy, Chap. 4, Ithaca, New York: Cornell University Press, pp. 97-121.

Vikner, Sten (1985), "Reichenbach Revisited: One, two, or three temporal relations", Acta Linguistica Hafniensia, 19/2 (1985), pp. 81-98.

Wöllstein-Leisten, Angelika, Axel Heilmann, Peter Stepan, Sten Vikner (1997), Deutsche Satzstruktur. Grundlagen der syntaktischen Analyse, Tübingen: Narr.

\section{NOTER}

1 Det er i øvrigt også interessant at se, at de danske versioner i b)-eksemplerne ikke er så entydige som de tyske i forhold til deres aspekt-interpretation. Tidspunktet, hvor Klaus bemærkede, at det var lyst i (2b), bliver fortrinsvis interpreteret som liggende efter det tidspunkt, han kom hjem. Vil man fremkalde den imperfektive læsning i det danske eksempel, bliver man nødt til at benytte sig af yderligere leksikalske midler, som fx adverbialet på vej ved bemoerkede.

2 Der er flere måder at klassificere verbale udtryk på. I Duden (1998) findes fx en inddeling efter absolutte (schlafen, krähen), relative (loben, gedenken), refleksive verber (sich aneignen, sich schämen) og funktionsverberne (zum Abschluss bringen). Denne klassifikation beror på verbernes forbindelsesegenskaber med hensyn til komplementernes antal og art. En anden klassifikationsmulighed er den kendte inddeling i "fuldverber" (ty. Vollverben), hjælpeverber, modalverber og "modificerende" verber (fx pflegen, scheinen). Også denne inddeling er baseret på verbernes syntaktiske adfærd, fx tager hjælpeverber andre verber i participium passiv eller i den nøgne infinitiv, modalverberne tager kun infinitiver, der igen kan kombineres med andre verber. Modificerende verber forbinder sig i denne klassifikation med $z u$-infinitiver. Begge klassifikationer er baseret på syntaktiske forbindelsesegenskaber, den første med nominale (herunder præpositionalgrupper), den anden igen med verbale enheder. Disse to klassifikationer kan forenes i et klassifikationsskema, idet man på det første niveau skelner mellem verber, der kan forbindes med andre verbformer (fx hjælpeverber, modalverber) og verber, der ikke kan forbindes (først og fremmest fuldverber). En sådan syntaktisk baseret klassifikation af verber står i modsætning til klassifikationer, der rent semantisk bliver opfattet som handlingsverber, forgangsverber og tilstandsverber (Duden 1998: 90) eller inddelingen i aktionsarter (Duden 1998: 90f.). De sidste to bliver præsenteret som rene betydningsgrupper, uden operationaliseringsmulighed og grammatiske reflekser. Det svarer ikke til den moderne opfattelse af aktionsart, som min drøftelse af grammatisk relevans ved aktionsarter i særdeleshed vil vise. 


\section{Engerer, Indledning}

3 Meget karakteristisk og især forvirrende, at der et sted bruges synonyme, alternative betegnelser for én aktionsart, mens der andetsteds bliver gjort forsøg på at differentiere. Eksempler er perfektiv/terminativ, inchoativ/ingressiv, resultativ/egressiv, punktuel/momentan, imperfektiv/ durativ m.m. (Duden 1998: 91). 